\title{
Association between $I L-4$ gene polymorphisms, IL-4 serum levels, and ankylosing spondylitis
}

\author{
X.L. Liu ${ }^{1}$, J.K. Ren ${ }^{2}$ and Y.L. Su ${ }^{1}$ \\ ${ }^{1}$ Clinical laboratory, Shangluo Central Hospital, Shangluo, China \\ ${ }^{2}$ Clinical laboratory, Shanxi Provincial People's Hospital, Xi'an, China \\ Corresponding author: X.L. Liu \\ E-mail: liuxiaoliang6003@163.com
}

Genet. Mol. Res. 15 (4): gmr15048898

Received June 17, 2016

Accepted September 5, 2016

Published October 17, 2016

DOI http://dx.doi.org/10.4238/gmr15048898

Copyright (C) 2016 The Authors. This is an open-access article distributed under the terms of the Creative Commons Attribution ShareAlike (CC BY-SA) 4.0 License.

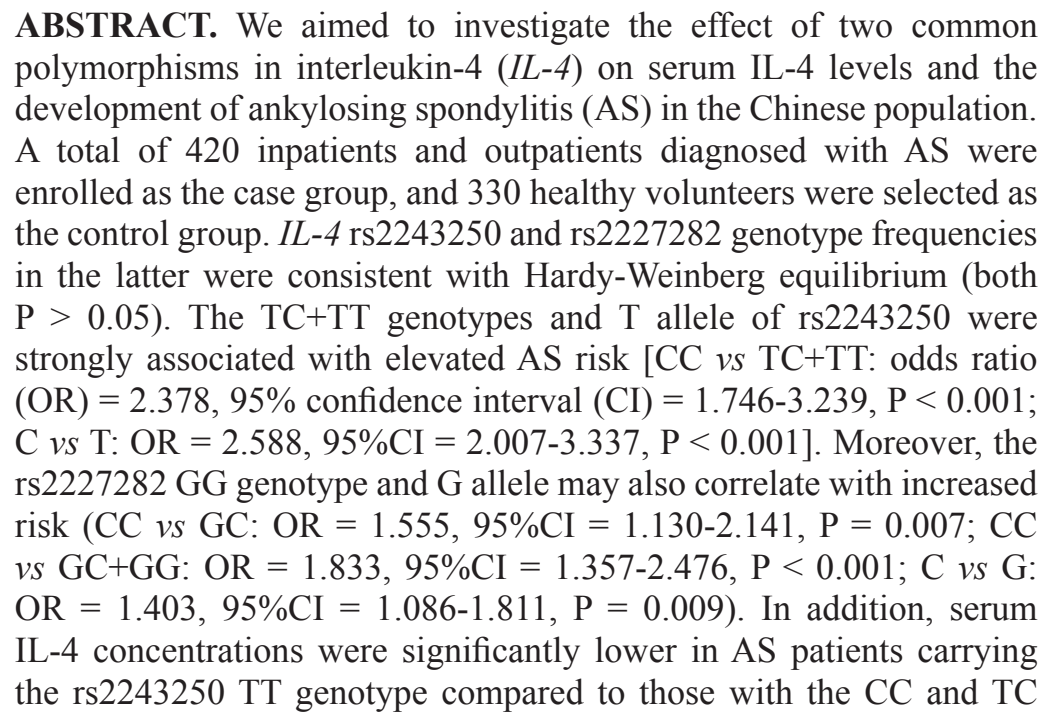

Genetics and Molecular Research 15 (4): gmr15048898 
genotypes (both $\mathrm{P}<0.05$ ). Similarly, patients carrying the rs2227282 CC genotype demonstrated higher serum IL-4 levels than those with the $\mathrm{GC}$ and $\mathrm{GG}$ genotypes (both $\mathrm{P}<0.05$ ). Our study provides evidence that IL-4 polymorphisms associated with diminished serum IL-4 levels may be partially responsible for AS development in the Chinese population.

Key words: Interleukin-4; Ankylosing spondylitis; Serum levels; Single nucleotide polymorphism; IL-4 rs2243250; IL-4 rs2227282

\section{INTRODUCTION}

Ankylosing spondylitis (AS) is considered a chronic and progressive inflammatory disease, and has been confirmed as an example of both inflammatory and autoimmune spondyloarthropathy (Chen et al., 2011). It primarily involves inflammation of the sacroiliac joint, which is seen as the hallmark of AS, and subsequently affects joints in the spine, resulting in progressive ankylosis and eventually involvement of the axial skeleton, causing the spine to fuse in a rigid formation known as bamboo spine (Huang et al., 2014; Kassimos et al., 2014). AS is the most common severe rheumatic disorder subtype, with a worldwide incidence rate between 0.1 and $1.4 \%$, and results in not only structural and functional physical impairments, but also decreased quality of life (Lee et al., 2013; Dean et al., 2014). It has been reported that the majority of AS cases involve young men (15-40 years old), with this disease rarely presenting after the age of 50 years (Kassimos et al., 2014). Clinical characteristics of AS may include stiffness, sleep disturbances, decreased spinal mobility, and psychological outcomes, including stress, anxiety, and depression (Baysal et al., 2011). Moreover, multiple complications are associated with AS, the most significant being renal failure and secondary amyloidosis (Kobak, 2012). Accumulating evidence suggests that its etiology is multifactorial, with principal influences resulting from the interaction between environmental and inherited risk factors (Boonen et al., 2010; Costenbader et al., 2012; Ma et al., 2013). In addition, inflammation-related processes may be partially responsible for the incidence and development of such diseases.

Interleukin-4 (IL-4), encoded by the $I L-4$ gene on chromosome $5 \mathrm{q} 23.31$, is a cytokine that induces the differentiation of naive helper T (Th) cells into Th2 cells, and is critical for regulating the Th1/Th2 immune response balance (Liang et al., 2011; Harada et al., 2012). Concerning its immunoregulatory and more general biological functions, IL-4 has been shown to be closely connected to the control of cell proliferation, differentiation, and apoptosis (Jenkins et al., 2013). Moreover, as a modulator of the human immune system, IL-4 is among the important multifunctional cytokines that may be involved in both humoral and adaptive immunity (Vijayanand et al., 2012). Acting as a lymphocyte growth and survival factor, IL-4 can stimulate activated B cell and T cell proliferation, and the differentiation of B cells into plasma cells (Toellner, 2014; Banchereau, 2015). More importantly, as an antiinflammatory cytokine, it can suppress the synthesis of pro-inflammatory cytokines, thereby exhibiting therapeutic effects in in vivo models of collagen-induced arthritis (Hemmerle and Neri, 2014). In the present study, we therefore evaluated its tissue-protective effect by investigating common single nucleotide polymorphisms (SNPs) in the $I L-4$ gene, namely, rs $2243250(-590 \mathrm{C} / \mathrm{T})$ and $\mathrm{rs} 2227282(+3437 \mathrm{C} / \mathrm{G})$, and IL-4 protein expression levels in AS patients.

Genetics and Molecular Research 15 (4): gmr15048898 


\section{MATERIAL AND METHODS}

\section{Ethics statement}

This study was approved by the ethics committee of Shangluo Central Hospital and was performed in strict accordance with the principles of the Declaration of Helsinki. Prior to the investigation, all eligible subjects were notified of the details of the study, and written informed consent was obtained from each subject.

\section{Subjects}

From October 2012 to May 2014, a total of 420 inpatients and outpatients with AS were recruited from Shangluo Central Hospital as the case group. The following inclusion criteria were applied: 1) diagnosis of AS was confirmed by clinical inspection and X-ray examination; 2) diagnosis was in line with the 1984 modified New York criteria (Goie The et al., 1985), as follows: i) lower back pain lasting for at least 3 months that is relieved by activity but not by rest; ii) movement of the lumbar spine and lateral flexion are limited; iii) thoracic expansion is lower than the normal values observed in groups of the same age and gender; iv) presence of bilateral sacroiliitis grades II-IV, or unilateral sacroiliitis grades III-IV. AS was diagnosed if any of criteria i-iii were met, in addition to criterion iv. We included 316 male and 104 female AS patients, aged 28-64 years (with a mean age of $45.71 \pm 13.68$ years), and with a mean disease duration of 15.50 years (ranging from 3-25 years).

A group of 330 healthy volunteers (270 men and 60 women aged $25-67$ years, with a mean age of $46.52 \pm 12.91$ years) were enrolled as the control group. No statistically significant differences in age or gender were observed between the groups (both $\mathrm{P}>0.05$ ). Individuals with systemic lupus erythematosus, Sjögren's syndrome, juvenile idiopathic arthritis, polymyositis, dermatomyositis, other autoimmune diseases, hereditary diseases, severe heart, lung, liver, or kidney dysfunction, benign or malignant tumors, or other related diseases were excluded from this study.

\section{Selection of candidate SNPs}

$I L-4$ SNPs were selected for this study from datasets representing the Han Chinese population in the HapMap (http://www.hapmap.org/) and National Center for Biotechnology Information dbSNP (http://www.ncbi.nlm.nih.gov/snp/) databases, based on the smallest allele frequencies (greater than 0.05). A review of the literature published in recent years revealed any associations with AS, systemic lupus erythematosus, rheumatoid arthritis, Crohn's disease, and systemic sclerosis. Finally, rs2243250 (-590C/T) and rs2227282 (+3437C/G), located on chromosome 5, were included in this study.

\section{Detection of $I L-4$ polymorphisms}

In the early morning, venous blood samples $(2 \mathrm{~mL})$ were collected from each patient and healthy control subject after an overnight fast, using ethylenediaminetetraacetic acid as an anticoagulant. Genomic DNA was extracted using a DNA Extraction Kit (Tiangen Biotech, Beijing, China) following the manufacturer protocol. The rs2243250 and rs2227282 SNPs in

Genetics and Molecular Research 15 (4): gmr15048898 
the $I L-4$ gene promoter were analyzed using real-time polymerase chain reaction (PCR). All primers for PCR amplification, the sequences of which are listed in Table 1, were designed using Primer Premier 5.0 (PREMIER Biosoft, Palo Alto, CA, USA). Amplification was performed in a $5-\mu \mathrm{L}$ reaction, including $0.95 \mu \mathrm{L} \mathrm{H}_{2} \mathrm{O}, 0.625 \mu \mathrm{L}$ PCR buffer (10X), $0.325 \mu \mathrm{L} \mathrm{MgCl}_{2}$ $(25 \mathrm{mM}), 1 \mu \mathrm{L}$ deoxynucleotides, and a mixture comprising $1 \mu \mathrm{L}$ each of the upstream and the downstream primers, $0.1 \mu \mathrm{L}$ HotStarTaq polymerase $(5 \mathrm{U} / \mu \mathrm{L})$, and $1 \mu \mathrm{L}$ template DNA. The reaction conditions were as follows: pre-denaturation $\left(94^{\circ} \mathrm{C}\right.$ for $\left.15 \mathrm{~s}\right)$, then 45 cycles of denaturation $\left(94^{\circ} \mathrm{C}\right.$ for $\left.20 \mathrm{~s}\right)$, annealing $\left(56^{\circ} \mathrm{C}\right.$ for $\left.30 \mathrm{~s}\right)$, and extension $\left(72^{\circ} \mathrm{C}\right.$ for $\left.1 \mathrm{~min}\right)$, before a final extension $\left(72^{\circ} \mathrm{C}\right.$ for $\left.3 \mathrm{~min}\right)$. After completion of this reaction, samples were stored at $4^{\circ} \mathrm{C}$. PCR products were then separated and analyzed by $2 \%$ agarose gel electrophoresis.

\begin{tabular}{l} 
Table 1. Sequences of primers used for polymerase chain reaction amplification of the rs 2243250 and \\
rs 2227282 regions of the $I L-4$ gene. \\
\hline \begin{tabular}{l|l}
\hline SNP & Primer \\
\hline rs2243250 (C/T) & F: 5'-ACTAGGCCTCACCTGATACG-3' \\
\cline { 2 - 2 } & R: 5'-GTTGTAATGCAGTCCTCCTG-3' \\
\hline \multirow{2}{*}{ rs2227282(C/G) } & F: 5'-TTTAGTGCAAGGCCTTAACGTTTA-3' \\
\cline { 2 - 2 } & R: 5'-TTGCTCTGGTATCGCAGCGAGGGGG-3' \\
\hline
\end{tabular}
\end{tabular}

$\mathrm{SNP}=$ single nucleotide polymorphism, $\mathrm{F}=$ forward, $\mathrm{R}=$ reverse.

\section{Enzyme-linked immunosorbent assay (ELISA)}

Serum IL-4 concentration was measured using an ELISA Kit (Boster Co., Ltd., Wuhan, China) following the manufacturer protocol. First, $100 \mu \mathrm{L}$ blood sample was put into each antibody-coated well, comprising $33 \mu \mathrm{L}$ plasma and $67 \mu \mathrm{L}$ diluent. Standard solution $(100 \mu \mathrm{L})$ at a range of concentrations was added into the nine corresponding wells, while the blank control well was left empty. The plate was then shaken until the samples were well mixed, before being sealed with adhesive plastic film and placed in an incubator at $37^{\circ} \mathrm{C}$ for $90 \mathrm{~min}$. Subsequently, the plate was removed from the incubator and the liquid in each well discarded. Washing solution comprising phosphate buffered saline solution $(350 \mu \mathrm{L})$ was added to the wells and removed after $30 \mathrm{~s}$, before drying the plate on absorbent paper. The above steps were repeated five times. Next, with the exception of the blank control well, 100 $\mu \mathrm{L}$ biotin-labeled antibody was placed in the wells, which were then sealed with tape and kept in a $37^{\circ} \mathrm{C}$ incubator for $60 \mathrm{~min}$. Following this, $100 \mu \mathrm{L}$ enzyme-conjugated antibody was added and the plate sealed with film. Reactions were then carried out for $30 \mathrm{~min}$ at $37^{\circ} \mathrm{C}$ in an incubator. After five washes, $100 \mu \mathrm{L}$ color-development reagent was pipetted into each well and allowed to react for 15-20 min, avoiding subsequent exposure to light. Finally, after mixing $100 \mu \mathrm{L}$ stop solution with each sample, optical density at a wavelength of $450 \mathrm{~nm}$ was measured immediately using an ELISA plate reader.

\section{Statistical analysis}

Statistical analysis was conducted using SPSS 19.0 (SPSS Inc., Chicago, IL, USA) based on experimental data represented as continuous variables (means \pm standard deviations) and counts (percentages). The $t$-test or analysis of variance was applied for comparisons between groups. The conformance of SNP genotype frequencies in the control group to

Genetics and Molecular Research 15 (4): gmr15048898 
Hardy-Weinberg equilibrium (HWE) was tested by Fisher's exact test. Genotype and allele distribution differences between groups are reported as odds ratios (ORs) and 95\% confidence intervals (95\%CIs). The chi-square test was employed for analysis of rs 2243250 and rs 2227282 allele and genotype frequencies. P values for all tests are two-tailed, and to limit the risk of false positive results, only those below 0.05 were considered statistically significant.

\section{RESULTS}

\section{Distribution of $I L-4$ genetic polymorphisms}

Frequencies of $I L-4$ polymorphism genotypes and alleles among AS patients and controls are displayed in Table 2. IL-4 rs2243250 and rs2227282 genotypes in the control group were distributed in accordance with HWE (both P > 0.05). Allele and genotype frequencies of these SNPs in the AS group significantly differed from those in the control group. Comparison of the AS patients and control subjects suggested that the frequency of the $I L-4$ rs 2243250 TT genotype and $\mathrm{T}$ allele were significantly higher among the former than the latter (TT genotype frequency: 18.09 vs $4.24 \%, \mathrm{P}<0.05$; T allele frequency: 32.62 vs $15.76 \%, \mathrm{P}<0.05$ ). We found that subjects carrying the rs $2243250 \mathrm{TC}+\mathrm{TT}$ genotypes or $\mathrm{T}$ allele were at a substantially increased risk of AS (CC vs TC+TT: $\mathrm{OR}=2.378,95 \% \mathrm{CI}=1.746-3.239, \mathrm{P}<0.001$; $\mathrm{C} v s \mathrm{~T}$ : OR $=2.588,95 \% \mathrm{CI}=2.007-3.337, \mathrm{P}<0.001)$. The $I L-4 \mathrm{rs} 2227282 \mathrm{GG}$ genotype frequency was $16.67 \%$ in the AS group, compared to $4.24 \%$ in the control group $(\mathrm{P}<0.05)$. In addition, the $\mathrm{G}$ allele of this polymorphism was detected in $24.87 \%$ of AS patients and $19.09 \%$ of controls $(\mathrm{P}<0.05)$. Similarly, the $I L-4 \mathrm{rs} 2227282 \mathrm{CC}$ genotype appears to be associated with increased AS risk $(\mathrm{CC}$ vs $\mathrm{GC}: \mathrm{OR}=1.555,95 \% \mathrm{CI}=1.130-2.141, \mathrm{P}=0.007 ; \mathrm{CC}$ vs $\mathrm{GC}+\mathrm{GG}: \mathrm{OR}=$ $1.833,95 \% \mathrm{CI}=1.357-2.476, \mathrm{P}<0.001)$, and the $\mathrm{C}$ allele with diminished risk $(\mathrm{C} v s \mathrm{G}: \mathrm{OR}=$ $1.403,95 \% \mathrm{CI}=1.086-1.811, \mathrm{P}=0.009)$.

Table 2. Distribution of rs 2243250 and rs2227282 alleles and genotypes.

\begin{tabular}{|c|c|c|c|c|c|}
\hline SNP & Cases $[\mathrm{N}=420]$ & Controls $[\mathrm{N}=330]$ & $\mathrm{P}$ & OR & $95 \% \mathrm{CI}$ \\
\hline \multicolumn{6}{|c|}{ rs2243250 } \\
\hline $\mathrm{CC}$ & $222(52.86 \%)$ & $240(72.73 \%)$ & Ref. & & \\
\hline $\mathrm{TC}$ & $122(29.05 \%)$ & $76(23.03 \%)$ & 0.001 & 1.735 & $1.236-2.437$ \\
\hline TT & $76(18.09 \%)$ & $14(4.24 \%)$ & $<0.001$ & 5.869 & $3.226-10.678$ \\
\hline $\mathrm{TC}+\mathrm{TT}$ & $198(47.14 \%)$ & $90(27.27 \%)$ & $<0.001$ & 2.378 & $1.746-3.239$ \\
\hline C allele & $566(67.38 \%)$ & $556(84.24 \%)$ & Ref. & & \\
\hline T allele & $274(32.62 \%)$ & $104(15.76 \%)$ & $<0.001$ & 2.588 & $2.007-3.337$ \\
\hline \multicolumn{6}{|c|}{ rs 2227282} \\
\hline $\mathrm{CC}$ & $206(49.04 \%)$ & $218(66.06 \%)$ & Ref. & & \\
\hline $\mathrm{GC}$ & $144(34.29 \%)$ & $98(29.70 \%)$ & 0.007 & 1.555 & $1.130-2.141$ \\
\hline GG & $70(16.67 \%)$ & $14(4.24 \%)$ & $<0.001$ & 5.291 & $2.891-9.686$ \\
\hline $\mathrm{GC}+\mathrm{GG}$ & $214(50.96 \%)$ & $112(33.94 \%)$ & $<0.001$ & 1.833 & $1.357-2.476$ \\
\hline C allele & $556(75.13 \%)$ & $534(80.91 \%)$ & Ref. & & \\
\hline G allele & $284(24.87 \%)$ & $126(19.09 \%)$ & 0.009 & 1.403 & $1.086-1.811$ \\
\hline
\end{tabular}

$\mathrm{OR}=$ odds ratio, $95 \% \mathrm{CI}=95 \%$ confidence interval, $\mathrm{SNP}=$ single nucleotide polymorphism.

\section{Comparison of serum IL-4 levels}

Data concerning comparisons of serum IL-4 levels between and within groups are presented in Table 3. IL-4 serum concentrations in the AS group were remarkably higher 
than those in the control group, and this difference was statistically significant $(\mathrm{P}<0.05)$. Concerning rs2243250, IL-4 levels were significantly lower in AS patients carrying the TT genotype than in those with the $\mathrm{CC}$ and TC genotypes (both $\mathrm{P}<0.05$ ). In addition, patients carrying the rs $2227282 \mathrm{GG}$ genotype also exhibited lower concentrations than those with the GC and CC genotypes (both $\mathrm{P}<0.05$ ). In the control group, however, serum IL-4 levels did not differ according to rs2243250 or rs2227282 genotypes (all $\mathrm{P}>0.05$ ).

Table 3. Comparison of serum IL-4 levels.
\begin{tabular}{l|c|c|c|c}
\hline & & Control group $(\mathrm{pg} / \mathrm{mL})$ & Case group $(\mathrm{pg} / \mathrm{mL})$ & P \\
\hline rs2243250 & CC & $295.74 \pm 62.11$ & $1433.29 \pm 214.88$ & $<0.001$ \\
\cline { 2 - 5 } & TC & $315.56 \pm 70.25$ & $989.38 \pm 150.37^{1}$ & $<0.001$ \\
\cline { 2 - 5 } & TT & $312.61 \pm 72.03$ & $569.65 \pm 101.23^{1}$ & $<0.001$ \\
\hline rs2227282 & CC & $281.11 \pm 62.87$ & $984.56 \pm 206.00$ & $<0.001$ \\
\cline { 2 - 5 } & GC & $288.20 \pm 69.93$ & $547.92 \pm 84.87^{1}$ & $<0.001$ \\
\hline
\end{tabular}

${ }^{1} \mathrm{P}<0.05$ compared with the corresponding wild-type homozygous genotype.

\section{DISCUSSION}

In the current study, we investigated the significance of rs2243250 and rs2227282, thought to be associated with altered serum IL-4 levels, in the incidence of AS. Furthermore, the relationship between these $I L-4$ gene variants and IL-4 serum concentration was systematically measured in AS patients. Our results suggest that the rs2243250 TT genotype is related to reduce IL-4 levels, and is also present at a higher frequency among AS patients than healthy controls. Similarly, the CC genotype of $I L-4$ rs 2227282 was associated with higher IL-4 serum concentrations, and was less common in the AS group. This suggests that the $I L-4$ rs 2243250 and rs2227282 polymorphisms significantly correlate with AS due to their lowering of IL-4 levels in serum.

At present, AS is generally thought to be associated with immunity, infection, and genetic factors (Wang et al., 2012; Cortes et al., 2013; van der Heijde et al., 2014); however, its exact etiopathogenesis has not yet been determined. Previous research has shown that CD4 ${ }^{+}$ Th cells, CD8 ${ }^{+}$cytotoxic T cells (Tc cells), and cytokines play vitally important roles in the pathogenesis of AS (Zhang et al., 2012; Cortes et al., 2013). For instance, Jin et al. (2013) confirmed the effect of $I L-1 R N$ polymorphisms on AS pathogenesis in the context of the related immune and inflammatory roles of associated cytokines. Importantly, Th cells are divided into Th1 and Th2 subgroups, and Tc cells into Tc1 and Tc2 subgroups, according to the cytokines that they produce (Noack and Miossec, 2014; Zhang et al., 2015). IL-4, secreted by Th2 and Tc 2 cells, functions to inhibit cell-mediated immunity and promote humoral immunity (Harada et al., 2012). It has been suggested that a Tc1/Tc2 imbalance is the critical factor leading to AS, but reports concerning this are scarce (Wang et al., 2015). In general, Th1 cells are pathogenic, whereas Th2 cells play a protective role; therefore, imbalance between these subsets is also key in AS pathogenesis (Limón-Camacho et al., 2012). In addition, polymorphisms of the $I L-4$ gene in patients with AS are likely to affect cytokine secretion patterns, and thus influence the progression of this disease. In the present study, we demonstrated that the rs 2243250 and rs2227282 SNPs of $I L-4$ may be associated with AS risk. A possible reason for this is that IL-4 is a pleiotropic T cell-derived cytokine, exerting either suppressive or stimulatory effects on different cell types, and involved in the regulation of humoral immune pathways (Burton 
et al., 2013). As an anti-inflammatory factor, IL-4 can inhibit the differentiation of naive T cells into Th1 cells, and the production of cytokines by these latter. Moreover, this cytokine, produced by activated $\mathrm{CD}^{+} \mathrm{T}$ cells, can promote Th2 cell maturation (Limón-Camacho et al., 2012). However, genetic polymorphisms in $I L-4$ that affect expression of the IL-4 protein contribute to a $\mathrm{T}$ cell imbalance, thereby potentially influencing its anti-inflammatory role and the development of AS (Wallis et al., 2011; Inanir et al., 2013).

Our study also revealed that serum IL-4 levels were substantially higher in AS patients than in healthy controls. Based on clinical data collected during the investigation, we observed significantly decreased IL-4 serum concentrations in patients with severe symptoms, high levels of inflammatory markers, and serious joint damage, suggesting that altered IL-4 production is strongly associated with disease activity in AS patients. Increased serum IL-4 may therefore have a protective function in this condition. Treatment with IL-4 mimics may thus help to alleviate symptoms, whereas IL-4 antibody administration clearly might aggravate arthritis, as reported in previous publications (Spiess et al., 2013; Suzuki et al., 2015). Considering its anti-inflammatory nature and protective effect in AS, decreased levels of IL-4 are associated with weakened inhibition of the inflammatory response (Bellini et al., 2012), leading to disruption of in vivo immune homeostasis, and promoting the development of immune-related diseases.

However, and importantly, the results of the present study should be interpreted with caution, since certain limitations to our work need to be taken into consideration. First, additional polymorphic loci in the $I L-4$ gene and other interleukins should be investigated to verify the role of cytokines in the progression of AS. Second, should time and funding permit, the association between $I L-4$ gene polymorphisms and clinical pathological features of patients with AS could be further investigated in future studies? Third, considering the current incidence and severity of AS, we would like to explore the potential of IL-4 antagonists in its prevention and treatment, by establishing animal models and clinical experiments. These approaches would certainly contribute to an in-depth investigation of cytokines involved in the development and prevention of AS.

In conclusion, variants of the $I L-4$ gene associated with decreased IL-4 serum levels may be implicated in the progression of AS. These findings may promote further investigation of the therapeutic role of IL-4 in AS, and perhaps in other related inflammatory or immune diseases. Fine-mapping studies are needed to confirm our results and establish the diagnostic and therapeutic potential of IL-4.

\section{Conflicts of interest}

The authors declare no conflict of interest.

\section{REFERENCES}

Banchereau J (2015). Generation of human B-cell lines dependent on CD40-ligation and interleukin-4. Front. Immunol. 6: 55. http://dx.doi.org/10.3389/fimmu.2015.00055

Baysal O, Durmuş B, Ersoy Y, Altay Z, et al. (2011). Relationship between psychological status and disease activity and quality of life in ankylosing spondylitis. Rheumatol. Int. 31: 795-800. http://dx.doi.org/10.1007/s00296-010-1381-x

Bellini A, Marini MA, Bianchetti L, Barczyk M, et al. (2012). Interleukin (IL)-4, IL-13, and IL-17A differentially affect the profibrotic and proinflammatory functions of fibrocytes from asthmatic patients. Mucosal Immunol. 5: 140-149. http://dx.doi.org/10.1038/mi.2011.60

Genetics and Molecular Research 15 (4): gmr15048898 
Boonen A, Braun J, van der Horst Bruinsma IE, Huang F, et al. (2010). ASAS/WHO ICF Core Sets for ankylosing spondylitis (AS): how to classify the impact of AS on functioning and health. Ann. Rheum. Dis. 69: 102-107. http:// dx.doi.org/10.1136/ard.2008.104117

Burton OT, Darling AR, Zhou JS, Noval-Rivas M, et al. (2013). Direct effects of IL-4 on mast cells drive their intestinal expansion and increase susceptibility to anaphylaxis in a murine model of food allergy. Mucosal Immunol. 6: 740750. http://dx.doi.org/10.1038/mi.2012.112

Chen WH, Yin HL, Lin HS and Chen CJ (2011). Symptomatic noncompressive motoromyelopathy presents as early manifestation in ankylosing spondylitis. Rheumatol. Int. 31: 945-950. http://dx.doi.org/10.1007/s00296-010-1614-Z

Costenbader KH, Gay S, Alarcón-Riquelme ME, Iaccarino L, et al. (2012). Genes, epigenetic regulation and environmental factors: which is the most relevant in developing autoimmune diseases? Autoimmun. Rev. 11: 604-609. http://dx.doi. org/10.1016/j.autrev.2011.10.022

Dean LE, Jones GT, MacDonald AG, Downham C, et al. (2014). Global prevalence of ankylosing spondylitis. Rheumatology (Oxford) 53: 650-657. http://dx.doi.org/10.1093/rheumatology/ket387

Goie The HS, Steven MM, van der Linden SM and Cats A (1985). Evaluation of diagnostic criteria for ankylosing spondylitis: a comparison of the Rome, New York and modified New York criteria in patients with a positive clinical history screening test for ankylosing spondylitis. Br. J. Rheumatol. 24: 242-249. http://dx.doi.org/10.1093/ rheumatology/24.3.242

Harada Y, Tanaka S, Motomura Y, Harada Y, et al. (2012). The $3 \square$ enhancer CNS2 is a critical regulator of interleukin4-mediated humoral immunity in follicular helper T cells. Immunity 36: 188-200. http://dx.doi.org/10.1016/j. immuni.2012.02.002

Hemmerle T and Neri D (2014). The antibody-based targeted delivery of interleukin-4 and 12 to the tumor neovasculature eradicates tumors in three mouse models of cancer. Int. J. Cancer 134: 467-477. http://dx.doi.org/10.1002/ijc.28359

Huang F, Gu J, Zhu P, Bao C, et al. (2014). Efficacy and safety of adalimumab in Chinese adults with active ankylosing spondylitis: results of a randomised, controlled trial. Ann. Rheum. Dis. 73: 587-594. http://dx.doi.org/10.1136/ annrheumdis-2012-202533

Inanir A, Yigit S, Tekcan A, Tural S, et al. (2013). IL-4 and MTHFR gene polymorphism in rheumatoid arthritis and their effects. Immunol. Lett. 152: 104-108. http://dx.doi.org/10.1016/j.imlet.2013.05.004

Cortes A, Hadler J, Pointon JP, Robinson PC, et al.; International Genetics of Ankylosing Spondylitis Consortium (IGAS); Australo-Anglo-American Spondyloarthritis Consortium (TASC); Groupe Française d'Etude Génétique des Spondylarthrites (GFEGS); Nord-Trøndelag Health Study (HUNT); Spondyloarthritis Research Consortium of Canada (SPARCC); Wellcome Trust Case Control Consortium 2 (WTCCC2) (2013). Identification of multiple risk variants for ankylosing spondylitis through high-density genotyping of immune-related loci. Nat. Genet. 45: 730738. http://dx.doi.org/10.1038/ng.2667

Jenkins SJ, Ruckerl D, Thomas GD, Hewitson JP, et al. (2013). IL-4 directly signals tissue-resident macrophages to proliferate beyond homeostatic levels controlled by CSF-1. J. Exp. Med. 210: 2477-2491. http://dx.doi.org/10.1084/ jem.20121999

Jin GX, Duan JZ, Guo WL, Li L, et al. (2013). Association between IL-1RN gene polymorphisms and susceptibility to ankylosing spondylitis: a large Human Genome Epidemiology review and meta-analysis. Genet. Mol. Res. 12: 17201730. http://dx.doi.org/10.4238/2013.May.21.3

Kassimos DG, Vassilakos J, Magiorkinis G and Garyfallos A (2014). Prevalence and clinical manifestations of ankylosing spondylitis in young Greek males. Clin. Rheumatol. 33: 1303-1306. http://dx.doi.org/10.1007/s10067-014-2574-6

Kobak S (2012). Efficacy and safety of adalimumab in a patient with ankylosing spondylitis on peritoneal dialysis. Rheumatol. Int. 32: 1785-1787. http://dx.doi.org/10.1007/s00296-010-1457-7

Lee SH, Lee EJ, Chung SW, Song R, et al. (2013). Renal involvement in ankylosing spondylitis: prevalence, pathology, response to TNF-a blocker. Rheumatol. Int. 33: 1689-1692. http://dx.doi.org/10.1007/s00296-012-2624-9

Liang HE, Reinhardt RL, Bando JK, Sullivan BM, et al. (2011). Divergent expression patterns of IL-4 and IL-13 define unique functions in allergic immunity. Nat. Immunol. 13: 58-66. http://dx.doi.org/10.1038/ni.2182

Limón-Camacho L, Vargas-Rojas MI, Vázquez-Mellado J, Casasola-Vargas J, et al. (2012). In vivo peripheral blood proinflammatory T cells in patients with ankylosing spondylitis. J. Rheumatol. 39: 830-835. http://dx.doi.org/10.3899/ irheum. 110862

Ma B, Yang B, Guo H, Wang Y, et al. (2013). The association between tumor necrosis factor alpha promoter polymorphisms and ankylosing spondylitis: a meta-analysis. Hum. Immunol. 74: 1357-1362. http://dx.doi. org/10.1016/j.humimm.2013.06.037

Noack M and Miossec P (2014). Th17 and regulatory T cell balance in autoimmune and inflammatory diseases. Autoimmun. Rev. 13: 668-677. http://dx.doi.org/10.1016/j.autrev.2013.12.004

Genetics and Molecular Research 15 (4): gmr15048898 
Spiess C, Bevers J, 3rd, Jackman J, Chiang N, et al. (2013). Development of a human IgG4 bispecific antibody for dual targeting of interleukin-4 (IL-4) and interleukin-13 (IL-13) cytokines. J. Biol. Chem. 288: 26583-26593. http:// dx.doi.org/10.1074/jbc.M113.480483

Suzuki A, Leland P, Joshi BH and Puri RK (2015). Targeting of IL-4 and IL-13 receptors for cancer therapy. Cytokine 75: 79-88. http://dx.doi.org/10.1016/j.cyto.2015.05.026

Toellner KM (2014). Cognate interactions: extrafollicular IL-4 drives germinal-center reactions, a new role for an old cytokine. Eur. J. Immunol. 44: 1917-1920. http://dx.doi.org/10.1002/eji.201444825

van der Heijde D, Zack D, Wajdula J, Sridharan S, et al. (2014). Rates of serious infections, opportunistic infections, inflammatory bowel disease, and malignancies in subjects receiving etanercept vs. controls from clinical trials in ankylosing spondylitis: a pooled analysis. Scand. J. Rheumatol. 43: 49-53. http://dx.doi.org/10.3109/03009742.201 3.834961

Vijayanand P, Seumois G, Simpson LJ, Abdul-Wajid S, et al. (2012). Interleukin-4 production by follicular helper T cells requires the conserved Il4 enhancer hypersensitivity site V. Immunity 36: 175-187. http://dx.doi.org/10.1016/j. immuni.2011.12.014

Wallis SK, Cooney LA, Endres JL, Lee MJ, et al. (2011). A polymorphism in the interleukin-4 receptor affects the ability of interleukin-4 to regulate Th17 cells: a possible immunoregulatory mechanism for genetic control of the severity of rheumatoid arthritis. Arthritis Res. Ther. 13: R15. http://dx.doi.org/10.1186/ar3239

Wang C, Liao Q, Hu Y and Zhong D (2015). T lymphocyte subset imbalances in patients contribute to ankylosing spondylitis. Exp. Ther. Med. 9: 250-256.

Wang CM, Ho HH, Chang SW, Wu YJ, et al. (2012). ERAP1 genetic variations associated with HLA-B27 interaction and disease severity of syndesmophytes formation in Taiwanese ankylosing spondylitis. Arthritis Res. Ther. 14: R125. http://dx.doi.org/10.1186/ar3855

Zhang L, Li YG, Li YH, Qi L, et al. (2012). Increased frequencies of Th22 cells as well as Th17 cells in the peripheral blood of patients with ankylosing spondylitis and rheumatoid arthritis. PLoS One 7: e31000. http://dx.doi.org/10.1371/ journal.pone. 0031000

Zhang L, Huang Y, Liu Z, Liu W, et al. (2015). Dynamics of T-cell subsets and their relationship with oral and systemic opportunistic infections in HIV/AIDS patients during the first year of HAART in Guangxi, China. J. Med. Virol. 87: 1158-1167. http://dx.doi.org/10.1002/jmv.24177

Genetics and Molecular Research 15 (4): gmr15048898 